\title{
Networks, sociabilities and health: the role of mental health support in Brazil
}

\section{Breno Augusto Souto Maior Fontes*}

\section{Abstract}

The occidental model of mental health support, dominant in Brazil, cannot be understood without considering nonprofessional curative practices and social representations of health and sickness. Here I summarize my research of the past several years on mental health and sociabilities, based on observation in institutions for mental health support in Brazilian cities.

Keywords: mental health, social networks, sociabilities.

* Federal University of Pernambuco, Recife, Pernambuco, Brazil. 


\section{A} s Janzen (1984) affirms, a holistic description of the medical system should take account of the varied curative practices in the society studied. And in the same way, it is impossible to comprehend the occidental model of mental health support, dominant in Brazil, without considering nonprofessional curative practices and social representations of health and sickness. Here I summarize my research of the past several years on mental health and sociabilities (Fontes, 2011; Fontes, 2013), based on observation in institutions for mental health support in Brazilian cities.

Various specialists have focused on mental disorders, which are a complex phenomenon, with polysemic constructions that incorporate discourses from psychiatry, psychoanalysis, the social sciences, various religions, "lay" forms of knowledge, among others. Mental disorders have become one of the principal problems of public health, presenting significant difficulties for others who interact with those afflicted - health professionals, relatives and everyday social networks (religious communities, friends, neighbors). Prevalence estimates are imprecise, due to the complexity of the phenomenon and the resulting difficulty in establishing conclusive diagnoses, but researchers (Carvalho; McIntyre, 2017) suggest that between 20\% and $35 \%$ of the Brazilian population suffers from less severe forms of mental disorder (anxiety disorders, affective disorders and low-grade depression).

Most people with psychic suffering seek relief in their communities of origin and in familiar territories. They are people who, in their therapeutic itineraries, in addition to seeking care from health professionals, use resources mobilized through their egocentric networks, combining popular knowledge and religious beliefs. Everyday sociabilities provide possibilities for mobilizing resources, including those oriented to self-care. Rural communities manifest a specific kind of territoriality, suggesting sociocentric networks different to those seen in urban areas. The ways in which people face everyday adversities in their territories, and the ways in which their egocentric networks are important to this, constitute central questions explored in this research agenda (Fontes, 2010).

In fact, considering the sociabilities derived from egocentric networks implies admitting the importance of social support - and equally the effects 
of negative interactions, such as stigma (Fontes, 2019). There is consensus among health specialists that the integration of the basic care team in the territory of those assisted is strategic to achieving positive results. And this fact also implies that the healthcare system should be evaluated holistically, always in dialogue with caring practices that are not part of conventional western medicine.

My research agenda focuses on social networks and health, including mental health and forms of care that replace the asylum model. The Psychosocial Care Centers (CAPS - Centros de Atenção Psicossocial) and the Family Health Units, both part of the Brazilian national health system (SUS- Sistema Único de Saúde), but locally administered, are the institutional anchors of these practices and are philosophically grounded in active community participation, family ties and interdisciplinary approaches to mental disorders. Networks thus emerge as a powerful instrument for explaining associative practices, manifested in movements of neighbors, friends and relatives that build solidarity.

But the reality of the mental health care units within the SUS is different, although their existence does underscore the importance of taking network phenomena into account and thus integrating the territory. In the case of the CAPS, for example, Amarante and Torre (2010) point out that the asylum model described by Goffman (1974) - and whose origins were described in 1961 by Foucault (2008) - is often reproduced on a smaller scale in the CAPS units, a fact that also became evident in my research, which showed the lack of regular interaction between the CAPS team and the territory in which it is located (Fontes, 2010). The Family Health Teams also manifest difficulties in forming effective ties to users' networks. My recent research (Fontes, 2019) shows that, despite the recommendations of the Ministry of Health, the basic care units have significant difficulties in communication with the communities they serve. This is a complex phenomenon that derives, on the one hand, from professional discourse distant from that dominant among users, which means that patients often cannot understand what doctors say and cannot make themselves understood adequately. On the other hand, it also derives from the difficulty of health 
teams (doctors, nurses, and to a lesser degree community health agents) in including traditional curative practices in their routines. The hegemony of medical discourse becomes an important obstacle to comprehension of the lifeworld of the people served. And this is also evident in mental health care, in which the dominant practice is the prescription of pharmaceuticals. In the Health Units observed there was significant occurrence of mental disorders (between $15 \%$ and $20 \%$ of the adult population), and medical practice for mental health clearly focused almost exclusively on prescription of psychopharmaceuticals, leading to the abandonment of some traditional remedies such as infusions, baths and prayers. Even conversation, talking therapy, is rarely used. The biomedical field has colonized traditional curative practices, and psychopharmaceuticals have become a kind of panacea for all ills, including those resulting from the normal afflictions of life.

This approach to health research, emphasizing social networks, allows better comprehension of the complex practices of care and healing, which can only be understood by studying the interconnections between the social networks of those afflicted by psychic suffering and the institutions of the health field (Fontes, 2018). This research - privileging processes and spaces of sociability underlying healing practices - allows identification of the principal obstacles to achieving the mental health care objectives of the Brazilian psychiatric reform, which was a great conquest for public health. Thinking about networks and health implies trying to comprehend the complex search for wellness, and the inscription of its meanings in the human existential universe, as well as revealing the signs of a good life (Fontes, 2016).

Publications summarized: Fontes, 2019; Fontes, 2016 and Fontes 2010.

Breno Augusto Souto Maior Fontes holds a PhD in Studies of Latin American Societies and is Professor at the Department of Social Sciences and Graduate Program of Sociology at the Federal University of Pernambuco, Brazil.

ఏbrenofontes@gmail.com. 


\section{References}

1. AMARANTE, Paulo; TORRE, Eduardo. 30 anos de reforma psiquiátrica brasileira: lutando por cidadania e democracia na transformação das políticas públicas e da sociedade brasileira. In: FONTES, Breno; DA FONTE, Eliane. Desinstitucionalização redes sociais e saúde mental: análise de experiências da reforma psiquiátrica em Angola, Brasil e Portugal. Recife: Editora da UFPE, 2010. p. 113-137.

2. CARVALHO, André; MCINTYRE, Roger S. Mental disorders in primary care: a guide to their evaluation and management. Oxford: Oxford University Press, 2017.

3. FONTES, Breno A. S. M. A terapia comunitária enquanto instrumento para a construção de práticas de cuidado: uma abordagem a partir das redes sociais. Ciências Sociais Unisinos, v. 55, n. 3, p. 411-423, set/dez 2019. http://revistas. unisinos.br/index.php/ciencias_sociais/article/view/csu.2019.55.3.10/60747579

4. FONTES, B. A. S. M. Redes sociais e governança em saúde. Ciência \& Saúde Coletiva, v.23, p.3123 - 3132, 2018. http://www.scielo.br/pdf/csc/v23n10/14138123-csc-23-10-3123.pdf

5. FONTES, Breno A. S. M. In search of happiness: Health, quality of life, and sociability. Sociologies in Dialogue, v.2, p.199 - 224, 2016. http://www. sbsociologia.com.br/sid/index.php/sid/article/view/30

6. FONTES, Breno A. S. M. Redes sociais e saúde mental. In: MARTINS, Paulo H.; PORTUGAL, Sílvia (orgs.) Cidadania, políticas públicas e redes sociais. São Paulo: Editora Anna Blume, 2011, v.01, p. 105-113.

7. FONTES, Breno A. S. M. Redes sociais e enfrentamento do sofrimento psíquico: sobre como as pessoas reconstroem suas vidas. In: FONTES, Breno; DA FONTE, Eliane. Desinstitucionalização redes sociais e saúde mental: análise de experiências da reforma psiquiátrica em Angola, Brasil e Portugal. Recife: Editora da UFPE, 2010, p. 355-389.

8. FONTES, Breno A. S. M.; PORTUGAL, S. A análise das redes sociais: o caso da saúde mental In: ALVES, Fátima (org.) Saúde, medicina e sociedade: uma visão sociológica. Lisboa: Pactor, 2013, p. 179-202.

9. FOUCAULT, Michel. História da loucura na Idade Clássica. São Paulo: Perspectiva. 2008.

10. GOFFMAN, Erving. Manicômios, prisões e conventos. São Paulo: Editora Perspectiva, 1974.

11. JANZEN John M. The quest for therapy: medical pluralism in Lower Zaire. Berkeley: University of California Press, 1984.

Received: Dec. 4, 2018. Accepted: Feb. 10, 2020. 
